\title{
D, WAEENINGEN
}

The humanitarian protectorate of South Sudan? Understanding insecurity for humanitarians in a political economy of aid*

Jansen, B.J .

This is a "Post-Print" accepted manuscript, which has been published in "The Journal of Modern African Studies"

This version is distributed under a non-commencial no derivatives Creative Commons (c) (1) () $\Theta$

(CC-BY-NC-ND) user license, which permits use, distribution, and reproduction in any medium, provided the original work is properly cited and not used for commercial purposes. Further, the restriction applies that if you remix, transform, or build upon the material, you may not distribute the modified material.

Please cite this publication as follows:

Jansen, B.J . (2017) The humanitarian protectorate of South Sudan? Understanding insecurity for humanitarians in a political economy of aid*. The Journal of Modern African Studies 55, p. 349-370

You can download the published version at:

https://doi.org/10.1017/S0022278X17000271 


\title{
The humanitarian protectorate of South Sudan? Understanding insecurity for humanitarians in a political economy of aid*
}

\author{
BRAM J. JANSEN \\ Sociology of Development and Change, Wageningen University \\ P.O. box 8130, Wageningen, The Netherlands \\ bramj.jansen@wur.nl
}

\begin{abstract}
This paper aims to contribute to debates about humanitarian governance and insecurity in post-conflict situations. It takes the case of South Sudan to explore the relations between humanitarian agencies, the international community, and local authorities, and the ways international and local forms of power become interrelated and contested, and to what effect. The paper is based on eight months of ethnographic research in various locations in South Sudan between 2011 and 2013, in which experiences with and approaches to insecurity among humanitarian aid actors were studied. The research found that many security threats can be understood in relation to the everyday practices of negotiating and maintaining humanitarian access. Perceiving this insecurity as violation or abuse of a moral and practical humanitarianism neglects how humanitarian aid in practice was embedded in broader state building processes. This paper posits instead that much insecurity for humanitarian actors is a symptom of the blurring of international and local forms of power, and which mediates the development of a humanitarian protectorate.
\end{abstract}

\section{INTRODUCTION}

Humanitarian action is increasingly understood as part of peace-building agendas and is associated with processes of global governance, in which international actors manage and intervene in the sovereign affairs of conflict-affected and fragile states in intimate ways (Duffield 2007; Agier 2011; Barnett 2011; Donini 2012; Fassin 2012). It is related to the will to transform societies and build states that are able to deal with political conflict in ways that don't result in war (Duffield 2002; Bliesemann de Guevara 2012a: 15). Simultaneously however, humanitarian action also remains a particular field of principled activities that aspire to aid people in need, separated from other forms of collaborative international engagement and power. This presents us with a paradox of humanitarianism: what happens under its label

\footnotetext{
* Thanks go to Prof. Dr. Dorothea Hilhorst and Prof. Dr. Bram Büscher, and two anonymous reviewers at the Journal of Modern African Studies for their insightful comments on this text. The fieldwork was supported by the Dutch Organisation for Social Scientific Research (NWO-Wotro).
} 
is both embedded in political processes of post-conflict state building and exceptional as principled emergency relief.

However, the ways in which this paradox materializes in practice, and the specific challenges that result from this, are poorly understood. Much academic debate tends to shy away from this ambiguous paradox and perceives this as a politicization, erosion or misunderstanding of a pure and moral humanitarianism, or as unintended consequences of a mandate shift in which humanitarianism somehow got mixed up with geo-political interests and aspirations. These understandings fail to grasp how contemporary humanitarian governance is a manifestation of the internationalization of non-western states, in which international and local forms of power are blurred. This is not action gone wrong, or a misunderstanding of norms and principles, but rather a post-political humanitarianism that takes on governmental aspirations, but is too narrowly understood, legitimized and communicated as normative, principal and practical action.

In this paper I take the case of South Sudan to explore this paradox of humanitarian aid as both exceptional and embedded action, and the consequent blurring of international and local forms of power and its effects. In December 2013 South Sudan relapsed into civil war after a peace agreement in 2005 and separation from Sudan in 2011 had allowed for a fragile peace. After the escalation at the end of 2013, questions arose over whether the international community, a broad assemblage of actors comprised of the UN, donor states, international NGOs and other actors, had allowed for, or even fostered, the escalation of the political situation in the new state. This followed the idea that war, peace and intervention produced a state in which the international community was accorded, and accorded itself, a place and influence in the governance of the new country.

This was not uncontested however, and over the years aid actors were increasingly faced with hostility, threats, appropriations of aid assets, and insecurity at the hands of local authorities. In this context, the maintenance of humanitarian aid roles in South Sudan necessitated continuous negotiations with local authorities, that increasingly appropriated, hindered, frustrated or attacked aid efforts, or threatened to do so, or allowed this to occur by third parties. Usual explanations about this form of insecurity dwell on the South Sudanese authorities as dysfunctional, inexperienced, corrupt or nepotistic, and offer limited reflection on humanitarianism itself, and its relations with the authorities and power holders in South 
Sudan. Instead, in this paper I analyse how processes of negotiating humanitarian access contributed to the consolidation of a particular political economy of aid, in which insecurity played a mediating role. It offers an understanding of insecurity facing aid agencies, and the ways this is managed, that recognises the ambiguous roles that humanitarian agencies themselves occupied in the creation and maintaining of what can be visualised as a humanitarian protectorate in South Sudan.

\section{WAR TO PEACE AND BACK AGAIN}

On the evening of 15 December 2013, shootings broke out in the Giada Barracks of the Sudanese People's Liberation Army (SPLA) in Juba, the capital of South Sudan. As the violence escalated over the following days, it spread from the barracks further into Juba, and then to the north, onto the towns of Bor and Malakal. It was unclear what exactly happened in these first hours and days. Explanations for the escalation ranged from a coup attempt by the deposed Vice-President Riak Machar - which was the official government line, to a forced disarmament of Nuer soldiers in the Presidential Guards Brigade, a mutiny that had triggered a violent response, to ethnic struggles within the Sudan People's Liberation Movement (SPLM) (D. H. Johnson 2014; Thomas 2015). When President Salva Kirr emerged in a televised press conference in military uniform, it became clear that after only two and a half years of independence, South Sudan was experiencing an escalation of conflict that, unlike several other regional insurgencies that had been plaguing the county in the postindependence years, had the potential to grow out into an all-out civil war. And it did.

Relations between the main political leaders had already been sour for some time. As violence spread and became partly organized along ethnic lines, people used labels such as 'ethnic conflict' to explain the upsurge of war, while others constructed a more elaborate picture of how power politics in South Sudan is associated with patronage systems, and that ethnicity was only a partial driver for the conflict, and more a consequence than a cause.

The latter genre of explanations implies that state power in South Sudan has been a matter of keeping various factions and potential volatile and disruptive elements in line by including them in a 'kleptocratic elite' (De Waal 2014). As a result, various pockets of rebellion that arose since (and before) independence have been dealt with by integrating rebel forces into the government army, and rewarding rebel factions with rents, or high positions in government or the army (Thomas 2015), indicating that the government instead of a 
monolithic body, rather represented a herogenous constellation as the outcome of bargaining among contending elites (Twijnstra 2015). As a result of these patterns of patronage, a politico-military elite has consolidated a neo-patrimonial rule, more engaged with accommodating its power constituency than with building a viable state and state institutions (De Waal 2014; Pinaud 2014). State resources were siphoned off to this elite to such an extent that even the considerable resources that the new state had access to vanished into satisfying this patronage network and personal gain. In De Waal's reading of the clashes, diminishing oil revenues due to an oil shutdown in the previous year, and plain greed, meant that by 2013 there were no resources available to keep the patronage system running, and things fell apart. There were signs preceding this: political quarrels and the reshuffling in the ruling SPLM party and government earlier in 2013, such as the stripping of power of the Vice President.

Corruption had been a word on many lips in the international community, including humanitarians, since the new state's inception. Although presented as endemic, many donors and aid actors regarded corruption as an abuse of the system - a flaw which they targeted with their programmes of post-conflict state-building, with the intention of strengthening the very state institutions able to combat this abuse. Yet as De Waal (2014) argues, instead of an abuse of the system, corruption was the system. Similarly, Young notes: 'under the guidance of the internationals the SPLA constructed a state in the image of the West, but it was only about appearances and virtually nothing functioned except the systematic looting of state coffers by its leaders' (Sudan Tribune 2015).

Where do the humanitarians who were operating in the post-conflict spectacle of South Sudan fit into this story? Many voices argued that South Sudan became independent too early, pushed by the US government, Hollywood stars such as George Clooney (D. H. Johnson 2014: 301) and the political lobby of the self-proclaimed 'Friends of South Sudan' ${ }^{1}$ that implemented the Sudanese peace negotiations as a form of "elite accommodation" (Sudan Tribune 2015). A leaked African Union report of the Commission of Inquiry on South Sudan, evaluating the 'political meltdown' after December 2013, places direct blame on the political backers and peace mongers of 'the Troika' (the US, the UK and Norway the main donors to the Comprehensive Peace Agreement (CPA), and holds them responsible for 'its decisive role in framing an agreement that set up a politically unchallenged armed power in South Sudan, one that could act with impunity, thereby legitimizing both anyone holding a gun and the rule of the gun.' 2 The report caused a public outcry and was withdrawn. ${ }^{3}$ 
These claims were pointed directly at donor states and the Troika or other unilateral or multilateral actors who were accorded a powerful role in steering and influencing South Sudanese politics, and not at humanitarian organisations, with their claim for a specific political niche that is distinct from the wider international arena. But on the ground, either more general forms of international assistance and donorship carried a humanitarian label in one way or another, or humanitarian agencies themselves were directly linked to or associated with the international aid system that was one of the driving forces in the post-conflict reconstruction of South Sudan.

The suggestion that humanitarianism may have contributed to shaping an 'abusive' political economy of aid is strongly related to the ambiguous position of humanitarian action as both exceptional and embedded. There is a need to develop a more critical understanding of this ambiguity for three reasons. First, because the arbitrary use - or rather multiple understandings - of the label 'humanitarian' presents a taken-for-granted ambiguity that is problematic. It is an operational term, and is applied and acted upon by governments, donors, and aid agencies despite this ambiguity and may have certain effects, for instance with regard to understanding and approaching insecurity, as I will argue below.

The humanitarian community itself is diffuse. It is an arena in which different actors operate under different labels, such as post-conflict reconstruction, emergency relief, humanitarian or development aid, capacity building and many more (Goodhand 2002; Hilhorst \& Jansen 2010; Salomons 2015). Moreover, it is part of that wider international community, together with the UN apparatus, multilateral and donor organisations, states, individual (I)NGOs, private and military actors, in an 'international community' that is rarely defined (Veit 2010). Yet the label 'humanitarian' carries a distinctly different connotation than 'aid' or 'development,' and humanitarians position themselves vis-a-vis the state and others accordingly. The humanitarian principles neutrality, independence and impartiality serve as a way of selfidentification and legitimization, and are used - and believed - to claim safe access to people and territory. In this understanding, humanitarianism necessarily depends and acts on this image of action exceptional to the state and international politics. This 'necessary fiction' (Rieff 2011) thus sustains the taken-for-granted ambiguity of humanitarian aid. 
Second, the suggestion that international actors contributed to the consolidation of the South Sudanese politico-military elite, and sustained their neo-patrimonial organisation, implicitly discerns this international support as something external to the state. Aid is, in many ways, part of a political economy of the state, and the suggestion that humanitarianism remains an external intervention rests upon a combination of what Smirl (2015) refers to as a 'humanitarian imaginary', and an ideological and aspirational rationale of nongovernmentalism that becomes increasingly difficult to uphold. As others have noted, although humanitarian aid may start out as an external force, it becomes locally embedded once its programmes are being implemented, and increasingly comes to form what might be termed a form of hybrid governance (Büscher and Vlassenroot 2010; Veit 2010; Anderson 2012; Bliesemann de Guevara 2012b).

Third, much academic attention to (humanitarian) aid and peace-building is too 'aid-centric' and risks exaggerating the importance of aid and external aid interventions (Goodhand 2002: 841; Barnett 2008; D. H. Johnson 2014). As a result these approaches accord a specific role to organisational identities and discourses, that do not necessarily match realities on the ground. For instance, the stressing of principles may be understood as important, effective and relevant in the eye of the aid giver, but irrelevant to aid receivers and local authorities. It is important to reflect on how humanitarianism is represented in academia, and how emergency discourses and problem-solving perspectives shape our analyses (Bakewell 2008; Barnett 2008). Similarly, it is important to recognise the differences between how humanitarianism is represented and how it actually materializes on the ground may be tainted by aid centred and normative perspectives.

This paper explores how negotiating access is related to this ambiguous duality of exceptionalism and embeddedness of contemporary humanitarian governance. More specifically it looks at how aid actors perceived and organized these negotiations around understandings of (in)security. In the next paragraphs, after a short methodological note, I will first reconsider this paradox of a humanitarianism in relation to the political. Then I will discuss how humanitarian action became increasingly embedded as part of a humanitarian protectorate, which not only implies a political role and position in relation to the larger international community, including international military forces, but also inherently affects the relation between aid and the state. Lastly, I will discuss how this impacts on relations between humanitarian and state actors. I will argue that the gaining and maintaining of 
humanitarian access sustained a political economy of aid. The result is that refusing, frustrating or endangering access is not so much an abuse or misunderstanding of humanitarian assistance to people in need, but rather the mediation of a potentially powerful humanitarian protectorate.

\section{METHODOLOGY}

The study is based on ethnographic fieldwork carried out between February 2011 and December 2013, as part of a larger project studying aid and insecurity. Six field trips were made for a total of eight months, in which I visited and interviewed NGOs, UN agencies and government staff in their field locations and head offices. A considerable amount of data gathering had a more informal character, and comprised of conversations, observations and 'hanging out' with aid staff and local people in the everyday environment in which humanitarianism takes shape. The research population represents a mixture of international and national staff from humanitarian NGOs and UN agencies, local authorities, and the general public that I approached in various locations all over South Sudan, such as Juba, Rumbek, Wau, Yambio, Yei, Malakal, Bor and Aweil, but also many smaller places as part of a motorcycle journey criss-crossing 8 out of (then) 10 states to also get an understanding of humanitarian negotiations and programming in smaller field locations.

In order to gain an understanding of this environment and the experiences and positioning of aid actors, this study applied ethnography to study humanitarian agencies, rationales and programs and its effects, also referred to aidnography. This allowed for an actor oriented approach to study crisis response, in which contradictions, personality and positionality are taken into consideration to analyse how everyday practices, perceptions and perspectives of aid are the outcome of social negotiation.

Although problematic from a methodological point of view, almost without exception, this research took place under conditions of anonymity. As a result, the presented field data is largely void of references to specific UN and NGO agencies, and the people interviewed, and the locations where they took place. I trust that the general presentation of relevant field data and the theoretical embeddedness is sufficient for a valid support of my argumentation. From another angle, this very limitation also highlights how maintaining humanitarian access in South Sudan is a sensitive affair, and the condition of anonymity and other measures to 
conceal the identity of people and their institutional affiliations, is a case in point for the role of insecurity in the political economy of aid.

\section{HUMANITARIAN GOVERNANCE AND THE INTERNATIONALIZATION OF NON-WESTERN STATES}

References to humanitarian aid as a coherent set of activities that is distinct from development, human rights, or other forms of international action are problematic. Humanitarianism covers a range of ethical, practical and organizational identities and identifications, yet the label is consequently used without recognizing the inherent variability and multiplicity, and indeed taken for granted as a clear-cut concept (Donini \& Walker 2012). Instead, humanitarian practice is comprised of different discourses, expressions, aspirations, ethics and programmes, that often intersect or overlap, but also compete with each other as part of larger humanitarian aims (Lester \& Dussart 2014: 17).

Two distinct approaches to humanitarianism can be distinguished. One is a strictly nonpolitical idea, often referred to as a Dunantist (after Henri Dunant, the founder of the Red Cross), or minimalist humanitarianism. This approach emphasises principles such as humanity, neutrality, independence and impartiality as the main determinants and drivers of humanitarian aid. The other end of the scale shows a more politically embedded approach, referred to as a Wilsonian (after former US president and secretary-general of the League of Nations), or maximalist, approach (Goodhand 2002; Middleton \& O'Keefe 2006). Alternatively, these two poles are sometimes referred to as 'emergency humanitarianism', which restricts itself solely to life-saving activities and 'alchemical humanitarianism' which seeks to remove the causes of suffering, and moves closer to the field of development (Barnett 2011: 22).

Although many humanitarian actors position and identify themselves somewhere near the minimalist positions, in practice they allow themselves various degrees of politicization, and the two poles are much more practically and historically interrelated. One school of thought sees this politicization, or alchemical humanitarianism, as a recent post 9/11 development, and as a regression from an earlier period of 'successful', 'pure' and 'ethical' humanitarianism (Fassin 2012), in which the principles of impartiality, neutrality and independence were respected (Barnett 2011: 2-5; Smillie 2012). This idea of a pure and ethical humanitarianism fails to recognise other, inherently liberal, parallels to earlier modes of global governance that 
used the language of humanitarianism without taking such a principled position (Barnett 2011; Lester \& Dussart 2014; Redfield \& Bornstein 2011; Reid-Henry 2014; Smillie 2012).

Humanitarianism conveys several things at once: 'a structure of feeling, a cluster of moral principles, a basis for ethical claims and political strategies, and a call for action' (Redfield \& Bornstein 2011: 17). It includes the strictly principled stance of NGOs such as Médecins sans Frontières (MSF), the workings of multi-mandated NGOs such as Oxfam, the religious drives of groups like Samaritans Purse or the activism of Non-Violent Peace Force, but also the understanding of humanitarian NGOs as 'force multipliers' as uttered by US Secretary of State Collin Powell in the struggle for hearts and minds in the War on Terror (Barnett \& Weiss 2008) and the actual military action that took place under the label 'humanitarian intervention', such as during the Kosovo and Libya campaigns.

This broad understanding of humanitarianism as a 'collection of interventions' (Veit 2010) makes that there are many ways in which individual humanitarian action relates to target States and indeed to the notion of global governance. What they share in common however, is a motivation to intervene, that others have referred to as a 'will to care' (Reid-Henry 2014), or a 'will to govern' (Duffield 2007). They imply an entitlement to act and intervene on behalf of others, legitimized by narratives of disaster, emergency and crisis, which necessitate outside interference and allow international actors the space to do so.

As humanitarians became increasingly involved in post-conflict reconstruction, peace and state building and so on, they became part of wider political networks with other international actors that are not primarily driven by humanitarian considerations (Barnett 2011), and operational engagements are tied to the political agendas and funding of western governments, and as a result they are not politically neutral and not impartial (Collinson \& Duffield 2013: 10; Hammond 2008). Rather, they are part of a 'mobile sovereignty' joined in a 'common project of the need to intervene' (Pandolfi 2010: 239).

These 'laboratories of post-national democracy' (Pandolfi 2010) are states of exception, in which the power of the interveners takes on an extra-legal quality that involves the imposition of the very logic of intervention - the humanitarian idea (Agier \& Bouchet-Saulnier 2004). Goodhand notes how "the aid community used the motif of the "failed state" to assume and justify itself as a "surrogate government”' (2002: 844). The result is the internationalization of 
(non-western) states, with associations and labels as 'white jeep states' (Sampson in Redfield \& Bornstein 2011: 24), 'governance states' (Bliesemann de Guevara 2012a: 11), or 'statebuilding states' (Anderson 2012), all of which indicate a blurring of international and local forms of governance, and accord a powerful role for the international aid community in local governance.

The merging of humanitarianism with post-conflict state building, peace building and military intervention resonates with a 'post-politics' of aid, in which humanitarianism is proclaimed as exceptional, temporary, and ethical action, while its outcome and praxis shows intimate forms of political governance and steering. Stern and Öjendal (2010) note a similar tendency in 'development', noting the gap between what is done in the name of development and what development actually is on the ground. The recognition of post-humanitarianism as a 'trompe l'oeil' (Apthorpe 2011), an image of ethical, non-political action which becomes something else the very moment it materializes, is one useful way of viewing the ambiguities of humanitarian governance.

However, the power behind the governmental roles and public service delivery of international aid remains elusive. Andersen uses the phrase 'tacit trusteeship' to capture this blurring of international and local authority in post-conflict state-building interventions, in which international control is 'neither entirely imposed on the state, nor fully voluntary' (2012: 133). She goes on to say that 'international authority must remain undeclared as a result of the paradoxical effect of both controlling and empowering (ibid). In other words, in order for international actors to build and support a legitimate state, their influence and power need to remain tacit, otherwise they compromise the very legitimacy of the state they are seeking to build. The language of partnership, capacity building and cooperation is all part of this package of tacit trusteeship, yet on the ground, the values implied in this arrangement, such as equality, participation and sharing, take on a different shape, and brings different power processes to light.

In humanitarianism, forms of tacit trusteeship manifest in language, labels and principles, representing action as temporary, non-political and external support. Yet in practice, reverberating Duffield's image of a 'radicalization of aid', humanitarian programmes manage people, ideas, and space, in collaboration with local authorities and other agencies, instigated by the desire to link relief to development and the experiment of post-conflict reconstruction. 
As a result, humanitarians that stressed their exceptionality and independence towards nonhumanitarian programs and other actors in the international community, simultaneously had become embedded with them in various ways, not only in terms of programming, but also with regards to security management.

\section{THE HUMANITARIAN PROTECTORATE OF SOUTH SUDAN}

When I visited Pibor town in Jonglei state at the end of 2012, new humanitarian structures had just been rebuilt after being destroyed when the town was overrun by a militia at the end of 2011. An estimated 8,000 ethnic Nuer youth, who called themselves 'the White Army', marched into Pibor; the terrified Murle population fled into the bush, aid staff were evacuated, and the town's infrastructure was destroyed.

One year later, the aid agencies rebuilt their compounds adjacent to the new compound of the Indian Battalion of the United Nations Mission in South Sudan (UNMISS). The walls around the UNMISS compound were unmistakably higher than those of the humanitarians', which were little more than thorn fences, apart from the sections where their compounds touched. The soldiers and the humanitarians were only separated by this wall, but in case of threat or emergency, humanitarian staff could quickly enjoy the 'force protection' of the Indian soldiers and evacuate to their compound, and from there get into UNMISS helicopters or those of the United Nations Humanitarian Air Service (UNHAS).

On the other side of town were some other compounds close together, a loosely fenced NGO campsite, where other groups found housing; a corporate organization, rather indistinguishable from an NGO, lodged here too. The adjacent compound housed a hospital and other NGO quarters. Several times a day, an Indian armed personnel carrier drove by to observe the situation, chat and move on. A fortnight before my visit there was a rebel attack and these aid staff were evacuated to the UNMISS compound where they spent the night. Spatially and practically the humanitarians and the wider mission were separate, yet they were together.

The material and spatial practices of humanitarian agencies are easily neglected due to the focus on programmatic goals, intentions and outputs (Smirl 2015). But the spatial organization of aid agencies in Pibor, and elsewhere in South Sudan, tells us something about their embeddedness and relationship with the larger international intervention. Although these 
aid actors existed independently, they organized themselves and related to each other in various ways when it comes to security measures. For instance, a cooperation agreement known as Saving Lives Together (SLT) was intended to keep aid flowing amid rising tensions and threats. ${ }^{4}$ The UN's security department was quite critical about this, stating that the NGOs made an effort in dissociating themselves from the UN all the time, in order to uphold their humanitarian image, but would expect and demand vehicles, aircraft and rescue if and when they needed to evacuate. In an insightful autobiographical account of an MSF staff in Abyei, Maskalyk remarks that 'much of the NGO work in Sudan, however little we liked to admit it, was entirely dependent on the United Nations' (2009: 34).

The tension between UN and NGOs, and NGOs amongst each other materialized in the everyday practices of coordination, cooperation and information sharing, or the lack thereof, as narrated in many examples by a variety of UN and NGO staff interviewed in places where NGOs group together, such as Rumbek, Yambio, Warrap, Bor, Wau and Juba, amongst others. While information sharing such as security updates raised tensions on an institutional level, this was less the case in the personal affiliations between the people that made up the international community. Here, the lines were blurred and came together in what has been aptly termed Peaceland (Autesserre 2014), or Aidland (Apthorpe 2011), a shared spatial organization of international agencies and their international staff, which may have differing humanitarian identities, yet who group together socially in compounds and for leisure, and with boundaries being crossed by staff rotations all the time. As I travelled the various regions in South Sudan, I met and hung out with aid workers from different denominations who congregated together in a shared architecture of “defensive living” (Duffield 2010), the odd mix of safari-style and semi-military camps in state capitals, such as Rumbek and Wau, as well as places such as in Warrap and Agok. These places breathed the air of a shared international environment where NGOs and UN congregated for reasons of convenience, security, entertainment and a lack of alternatives, and where they shared cars, information and resources, but also sustained an image of a privileged and protected international community.

De Waal notes how the invasion of Somalia, 'hailed as an experiment in taking over a formerly sovereign country as a sort of "humanitarian protectorate”' (2000: 39) was instigated by relief agencies. The goal was to create security for the delivery of relief assistance during famine. This represents a shift from protecting civilians to protecting humanitarian actors. The notion of 'force protection' also became clear in the attack on Pibor. Faced with the approach 
of the White Army, whose march took several days, the media called upon UNMISS to keep the peace and protect the people, but UNMISS declared that its mandate was to support the government (army) and to protect humanitarian staff. Many South Sudanese read UNMISS's mission differently and expected it to protect local people but, as was later explained in interviews, the protection of the 'mission' had top priority. (Since 2013, UNMISS has also taken on the latter role in their Protection of Civilians sites on compounds in Juba, Bentiu and Malakal where it hosts many thousands of people, a rather new development in (armed) humanitarian governance).

A protectorate refers to a state or period of being controlled and protected by another country, and recently, post-conflict measures have brought East Timor, Kosovo and Bosnia under transitional UN administration. Although there were advocates for establishing formal protectorates in parts of South Sudan, i.e. Abyei, ${ }^{5}$ or for the whole of the country, ${ }^{6}$ UNMISS was not a formal administrative takeover, yet it implicitly took on governing roles - partly shaped as humanitarian programmes and non-state public service delivery, and brought peacekeepers that carried arms to protect these efforts. Noteworthy are the white jeeps marked with 'UN police', traversing the streets of Juba and other state capitals that fed the image of a parallel government with many people on the streets.

Although aid and humanitarian assistance have been part of the political economy of Sudan, and later South Sudan, for decades, since UNMISS there has been an armed component protecting and enabling this humanitarian effort, but also tarnishing the voluntary nature of aid. UNMIS took shape after the signing of the Comprehensive Peace Agreement (CPA) in 2005, which ended a civil war that had lasted 22 years. After separation in 2011 UNMIS gained an S (for South) and became UNMISS - and was charged with monitoring the implementation of the CPA, and to provide support to the new government. As a UN 'integrated mission', the political, military and humanitarian domains of the UN were brought under a common organizational structure. The South Sudan project was hailed as a testing ground in post-conflict reconstruction and state building, and attracted unusually high commitment from UN member states (Pantuliano 2009; Thomas 2015: 82). This involved supporting, training, advising the state apparatus, and implementing programmes to serve the basic needs of the people, and the social infrastructure of the country. 
People I interviewed from government and both local and international aid staff, and local people, talked about aid and UNMISS in particular in terms such as a parallel authority or government. A main discourse on aid in South Sudan, voiced by many interviewees and UN reports, was that humanitarian programmes accounted for more than 90 per cent of service delivery. In effect, essential aspects of state administration have been managed and implemented by international aid agencies and the UN, and legitimized and framed as partnership, capacity building, technical assistance, and aid, visible in the many signposts, billboards and notifications from the international organisations. This is an embodiment of the 'tacit trusteeship’ that Anderson recognized in Liberia (2012).

The former Head of UNMISS, Hilde Johnson, wrote that 'it was the international NGOs that ended up bearing the brunt of social-service delivery to the Southern Sudanese, providing the population with basic healthcare and education, and building infrastructure in rural areas', and she saw reasons for concern here since this 'continued a pattern established during the civil war' (2011: 212) and arguably long before. International agencies became involved in the rebuilding and economic development of the southern part of what was then Sudan after the first civil war, from 1972 up to the outbreak of the second civil war in 1983, when NGOs and the UN became local substitutes for state administration (D. H. Johnson 2007; Riehl 2001). In 1989, six years after the second war broke out, UN agencies and NGOs, organized Operation Lifeline Sudan, providing emergency aid and basic services. This consolidated their role as service providers (Riehl 2001).

Many aid actors suggested that the South Sudanese authorities, and the population in general, had grown accustomed to aid coming their way. International aid workers referred to the taken-for-granted ways in which South Sudanese authorities claimed aid assets or sought to influence aid distribution and programmes. Several respondents argued that there was an 'entitlement attitude’ with local authorities seeking to control and influence humanitarian aid.

Humanitarians do not operate in a void, and countries recovering from war are no tabula rasa (Hilhorst et al. 2010), and authorities logically claimed their own sovereignty (not in the least because of the state building and empowerment rhetoric of the international agencies themselves). The humanitarian project, which by and large had embraced the twin aims of aiding people and building the state, needed to cooperate with state actors but did not want them to impede on humanitarianism itself, while local state actors wanted to have a say over 
the distribution of resources and ideas. Some NGOs experienced this as a shrinking of the 'humanitarian space', which became clear by an increase in harassments, administrative hurdles and security incidents. Others reasoned that the obstruction of aid could be interpreted as a way of countering a large and powerful collection of international interventions, and of laying claim to sovereignty. In this reading, the tacit trusteeship between the actors of the humanitarian protectorate and the South Sudanese state was mediated by insecurity.

In many ways, and on many levels, local authorities, the security forces, and other power holders such as local stakeholders, bureaucrats and politicians, contributed to insecurity for humanitarian actors. In response, addressing this insecurity in everyday processes of gaining and maintaining humanitarian access, consolidated a political economy of aid. In other words, for humanitarians to stay, they had to pay, or give way.

\section{ASPIRATION, SECURITY AND THE POLITICAL ECONOMY OF AID}

There is a well-documented history - if not a genre - of how aid in South Sudan was instrumentalised and manipulated by authorities and rebel parties (Millard Burr \& Collins 1995; Hutchinson 1996; De Waal 1997; Laverge and Weissman 2004; Marriage 2006; D. H. Johnson 2007; Keen 2008). The manipulation and instrumentalisation of aid is as old as humanitarianism itself (Magone et al. 2011; Donini 2012). In the insightful and reflexive (or perhaps apologetic) MSF publication 'Humanitarian negotiations revealed', Allie writes: 'the political exploitation of aid is not a misuse of its vocation, but its principal condition of existence'(2011). The symbols, principles and ethics of humanitarianism are advocated as universal, and the exploitation and instrumentalization of these are easily seen as the result of misunderstanding and confusion between aid givers and receivers (Hammond 2008). However, the claim that this is down to 'misunderstandings' is normative and aspirational, and draws attention away from the political economy of aid, and its longevity and historical precedent.

De Waal notes: 'over the years, SPLA officers became oriented towards an apparently unending supply of international humanitarian aid, which could be stolen with impunity’. He adds that 'NGOs and donors often connived in this' (2014: 352). In other words, NGOs allowed, condoned or facilitated the abuse of their aid. One reading of this is that accommodating demands of local authorities is a part of negotiating humanitarian access, in the sense of an 'acceptance' strategy in which aid actors seek to foster good relations with 
local authorities, power holders, and communities as a security strategy (Egeland et al. 2011). My fieldwork revealed how aid actors believed and experienced that confronting and challenging authorities and other stakeholders with what was in their eyes abusive or problematic behaviour towards the humanitarian imperative, had led to a loss of access, threats, or an early exit. From this perspective then, allowing a certain amount of abuse, can be understood as an aspect of a 'will to stay', and is in effect a form of manoeuvring around insecurity and negotiating access.

An interesting example was a government directive that stipulated that all aid that enters the country should remain there and be handed over to the state after aid programmes end, including humanitarian assets such as jeeps, office equipment, communication devices, and so on. Many interviewed staff had experiences with claims related to that directive. One NGO staff member explained how a local county authority in Raga forbade the NGO staff from crossing county boundaries in their vehicles, as they claimed that these belonged to the government. The NGO in question felt that it was being held hostage, and in the end they closed the programme. I encountered variations of this type of experience with other NGOs in other areas also.

Since all aid and aid infrastructure entering (South) Sudan, even during the implementation of the aid programme, was claimed as belonging to the government, local authorities felt a legitimate claim over humanitarian assets, and this puts notions of manipulation and abuse in a different light. These were not isolated incidents, or a phenomenon that only emerged after the CPA, but something that had its roots in a longer existing political economy of aid and predates South Sudan's separation (see also: D. H. Johnson 2007: 160). As a result, there was a constant struggle over humanitarian assets, their allocation and target audience and purpose, as part of cooperation between authorities and NGOs, that in many instances was aimed at the betterment of communities and constituencies of powerful local actors, but sometimes also for a more individual aim. For instance, there were claims that government staff owned NGO cars that they had appropriated and kept at home as their private property. I had lunch with one retired government staff who had two in his compound, still marked with NGO license plates.

Challenging, protesting over and confronting what humanitarians described as abuse, misconduct, or infringements to humanitarian access has led to what Jok refers to as 'bureaucratic war' (2007: 265) - involvig the imposition of extra taxes, regulations and 
permits. but also violent confrontations, arbitrary arrests of aid staff, and appropriation of aid assets. The insecurity facing aid organizations and aid workers was often the direct result of government, army or local authority actions - or inaction - that demanded resources and assistance from them (See also: Fast, et al 2011: 27: Bennett 2013: 5; Stoddard et al. 2012). ${ }^{7}$

Illustrative is an example of a hospital in Lakes state that was maintained, staffed and financed by an NGO that intended to hand it over to the state Ministry of Health after the initial phase. The NGO experienced threats and harassment because the state demanded that the NGO continue with its programme and was forced to continuing operating the program for some time, before abandoning the project, and the state, altogether due to the soured relation and the threats. Similar examples were given, with many having regular experiences of ministries or county officials seeking to influence the distribution of aid resources: where and when to stock clinics with medicines and other provisions, where to build schools, and who to employ, such as relatives and clan members. Through such strategies, local power brokers benefited their own communities and gained political legitimacy: they could claim aid delivery was the result of their own efforts to support their constituencies and they could make life difficult for NGOs if their demands were not met by rallying the very communities to act against the very aid agencies in case of non-compliance, or threats thereto.

In many cases, NGOs stayed but had to deal with demanding authorities and manoeuvre their way through these situations, by underplaying them, refraining from reporting them or complaining publicly, or finding other ways around the situation in order to remain operative. The UN Office for the Coordination of Humanitarian Affairs (OCHA) compiled and published a report about government abuses, harassment and neglect on behalf of NGOs, who feared retribution if they made independent reports. ${ }^{8}$

The question is to what extent not speaking out publicly against such threats and interference, turning a blind eye to it, providing a small kickback, or giving in to a demand from a specific authority, help consolidate and constitute an political economy of aid that is in part based on threat. The lines between an interfering authority, and a partnership where the local authority is accorded a decision making role, can be thin. It is not always clear what is abuse, and what is not, nor whether there is an infringement of humanitarian space, especially when humanitarian activities have crept into programmes of state building. Moreover, perceptions can differ between people and institutional mandates. During my field work it was difficult to 
distinguish concerns, principles, personal ethics, and institutional reputations. Aid actors presented and positioned themselves in the field in myriad ways, and there were large complexities and variations in the arrangements between them and government agencies.

One interviewee referred to the very rationale of the government seeking to restrict NGOs from a state perspective as misplaced, and stated: 'as if NGOs can undermine state sovereignty' implicitly dismissing the suggestion altogether. Yet, as Autesserre notes, 'the expatriates' narrative that they come to "help" host populations enables them to claim the moral high ground, while symbolic and material resources place expatriates in a dominant position' (2014: 250). This dominant position, and the claim for humanitarian space for maintaining operational presence and access, reflects the exceptionality that humanitarian workers lay claim to. However, these claims were countered by demands by local power holders seeking influence over aid assets and programmes. By thwarting aid, local authorities found a way to exert some sovereignty over the humanitarians, and other international actors. By making the humanitarians feel insecure the local authorities were able to keep a check on international interference, and indeed the roll-out of a humanitarian protectorate.

To return to Veit's (2010) exposé about intermediaries in indirect governance, it became clear during the interviews that for both aid workers and local authorities, access was very much, dependent on personal capacities, relations and motivations. As such we cannot adopt a blanket notion of corruption, neo-patrimonialism or abuse. Some collaborations with local authorities worked very well, while other areas were more challenging than others - the problematic states and regions could be pinpointed quite easily, for instance Raga, Lakes and Warrap were seen as notorious, whereas Western and Central Equatoria were considered more easy. To some extent these differentiations were part of ethnic relations between local and state power, specifically in Warrap and Lakes, which allowed for a certain impunity of local powerholders, that was absent in other areas. Yet in other places such as Jonglei and Unity, there was history of impunity due to local pockets of rebellion, and the armed responses of the state. As a general pattern, aid staff, almost without exception, saw the relations between them and state actors as difficult.

This resonates with Marriage's observation of the Sudanese government as 'a distant, antidevelopment force' (2006: 123). Although she was referring to a pre-separation context, observations since independence indicate that the government of South Sudan quickly became 
another (and according to some a more extreme) version of the Khartoum government when it comes to dealing with NGOs. One way of facing the powerful 'republic of NGOs' (as Schuller (2012) described Haiti, where NGOs tended to side line and bypass the government) is by creating insecurity, or other hurdles. Rather than being the outcome of a dysfunctional system, this might be instrumental in the sense of protecting sovereignty on the local level, or a sense thereof.

Humanitarians' 'will to stay' and their negotiating of humanitarian access is one way in which humanitarians become part of a neo-patrimonial network. As Veit notes about DRCongo, 'through reliance on powerful local forces, interventions are generally likely to modify, if not only reproduce, pre-conflict forms of political exchange, rather than being able to implement new patterns of power and domination' (Veit 2010: 36). In South Sudan this implies that aid actors have to negotiate their presence, balancing between practical considerations and principled ideas, thwarting authorities and circumventing local complexities. These may well include 'abuse' of aid resources, and legitimizing the very 'abusers' along the way, by accommodating them in one way or another because of the will to stay. The history and praxis of negotiating humanitarian access shows that it is difficult to separate humanitarian agencies from the patrimonial state. The paradox of humanitarianism, although opportunistically dissociated from the larger post-conflict intervention, is that it is simultaneously embedded as part of a wider humanitarian protectorate that is contested, challenged and opposed.

\section{CONCLUSION}

In this paper I have explored the relation between humanitarian aid and insecurity in South Sudan between 2011 and 2013. The experiences with insecurity for aid agencies at the hand of local authorities, armed forces and others, can be understood as part of everyday practices of negotiating and maintaining humanitarian access. Perceiving this insecurity as violations and abuses of a pure, moral and practical humanitarianism, reflects a narrow and problematic understanding of humanitarianism as normative, principal and practical action. Instead, humanitarian action in South Sudan in practice was largely embedded in broader peace and state building programmes and co-operations. Although many aid actors positioned themselves as principled and exceptional humanitarian actors, in practice they were part of, and maintained, a political economy of aid that was constantly negotiated and contested, particularly because of the governmental roles and to some extent aspirations of the international organisations. In this understanding, insecurity was a symptom of the blurring of 
international and local forms of power, and a check on a potentially powerful humanitarian protectorate.

\section{RESOURCES}

Agier, M. 2011. Managing the undesirables: refugee camps and humanitarian government. Cambridge: Polity Press.

Agier, M., \& F. Bouchet-Saulnier 2004. 'Humanitarian spaces: spaces of exception', in F. Weissman, ed. In the shadows of 'just wars': violence, politics and humanitarian action. New York: Cornell University Press, 297-313.

Allie, M. P. 2011. ‘Acting at any price?’, in C. Magone, M. Neuman \& F. Weissman, eds. Humanitarian negotiations revealed. The MSF Experience. London: C. Hirst \& Co Publishers Ltd, $1-13$.

Anderson, L. R. 2012. 'State building as tacit trusteeship: the case of Liberia', in B. Bliesemann de Guevara, ed. State building and state-formation. The political sociology of intervention. New York: Routledge, 132-148.

Apthorpe, R. 2011. 'With Alice in Aidland: a seriously satirical allegory', in D. Mosse, ed. Adventures in Aidland. The Anthropology of professionals in international development. New York: Berghahn Books, 199-219.

Autesserre, S. 2014. Peaceland. Conflict resolution and the everyday politics of international intervention. New York: Cambridge University Press.

Bakewell, O. 2008. 'Research beyond the categories: the importance of policy irrelevant research into forced migration', Journal of Refugee Studies 21, 4: 432-453.

Barnett, M. 2008. 'Humanitarianism as a scholarly vocation', in M. Barnett \& T. G. Weiss, eds. Humanitarianism in question. Politics, power, ethics. Ithaka: Cornell University Press, 235-263.

Barnett, M. 2011. Empire of humanity. A history of humanitarianism. Ithaka: Cornell University Press. Barnett, M. \& Weiss, T. G. 2008. 'Humanitarianism: a brief history of the present', in M. Barnett \& T.

G. Weiss, eds. Humanitarianism in question. Politics, power, ethics. London: Cornell University Press, 1-48.

Bennett, N. (2013). 'Humanitarian Access in South Sudan', Humanitarian Exchange. Special Feature: South Sudan at a crossroads. London: Humanitarian Practice Network / ODI, 5-7.

Bliesemann de Guevara, B. 2012a. 'Introduction: state building and state-formation', in B. Bliesemann de Guevara, ed. State building and state-formation. New York: Routledge, 1-20.

Bliesemann de Guevara, B. 2012b. Statebuilding and state-formation. The political sociology of intervention. New York: Routledge.

Büscher, K. \& K. Vlassenroot 2010. 'Humanitarian presence and urban development: new opportunities and contrasts in Goma, DRC', Disasters 34,S2, S256-S273. 
Collinson, S. \& M. Duffield 2013. Paradoxes of presence. Risk management and aid culture in challenging environments. London: Overseas Development Institute.

De Waal, A. 1997. Famine crimes: politics and the disaster relief industry in Africa. Oxford: James Currey.

De Waal, A. 2000. 'Wars in Africa', in M. Kaldor, ed. Global insecurity. London: Pintor 24-52.

De Waal, A. 2014. 'When kleptocracy becomes insolvent: brute causes of the civil war in South Sudan', African Affairs 113: 347-369.

Donini, A. 2012. The golden fleece. Manipulation and independence in humanitarian action. Sterling: Kumarian Press.

Donini, A, \& Walker, P. 2012. 'So what?', in A. Donini, ed. The golden fleece. Manipulation and independence in humanitarian action. Sterling: Kumerian Press, 243-263.

Duffield, M. 2002. 'Social reconstruction and the radicalization of development: Aid as a relation of global liberal governance’, Development and Change 33, 5: 1049-1071.

Duffield, M. 2007. 'Development, territories, and people: consolidating the external sovereign frontier’, Alternatives 32: 225-246.

Duffield, M. 2010. 'Risk-management and the fortified aid compound. Everyday life in postinterventionary society', Journal of Intervention and State building 4, 4: 453-474.

Egeland, J., A. Harmer \& A. Stoddard 2011. To Stay and deliver. Good practice for humanitarians in complex security environments. Geneva: OCHA.

Fassin, D. 2012. Humanitarian reason. A moral history of the present. Berkeley: University of California Press.

Fast, L., R. Patterson \& A. Amule 2011. South Sudan country report. Key findings from field research on acceptance in South Sudan. Washington, D.C.: Save the Children.

Goodhand, J. 2002. 'Aiding violence or building peace? The role of international aid in Afghanistan', Third World Quarterly 23, 5: 837-859.

Hammond, L. 2008. 'The power of holding humanitarianism hostage and the myth of protective principles', in M. Barnett \& T. G. Weiss, eds. Humanitarianism in question. Humanitarianism in question. Politics, power, ethics. Ithaka: Cornell University Press, 172-195.

Hilhorst, D., I. Christoplos \& G. Van Der Haar 2010. 'Reconstruction 'from below': a new magic bullet or shooting from the hip?’, Third World Quarterly 31, 7: 1107-1124.

Hilhorst, D. \& B. J. Jansen 2010. 'Humanitarian space as arena: a perspective on the everyday politics of aid', Development and Change 41, 6: 1117-1139.

Hutchinson, S. E. 1996. Nuer dilemmas. Coping with money, war, and the state. Berkeley: University of California Press.

Johnson, D. H. 2007. The root causes of Sudan's civil wars. Oxford: James Curry.

Johnson, D. H. 2014. 'Briefing: the crisis in South Sudan', African Affairs 113, 451: 300-309.

Johnson, H. F. 2011. Waging peace in Sudan. The inside story of the negotiations that ended Africa's 
longest civil war. Eastborne: Sussex Academic Press.

Jok, J. M. 2007. Sudan. Race, religion, and violence. Oxford: Oneworld Publications.

Keen, D. 2008. The benefits of famine. A poltical economy of famine \& relief in southwestern Sudan 1983-89. Oxford: James Currey Publishers.

Lavergne, M. \& F. Weissman 2004. ‘Sudan: Who Benefits from Humanitarian Aid?’, in F. Weissman, ed. In the shadow of 'just wars'. Violence, politics and humanitarian action. Ithaka, New York: Cornell University Press, 137-161.

Lester, A. \& F. Dussart 2014. Colonization and the origin of humanitarian governance. Protecting Aborigines across the nineteenth-century British empire. Cambridge: Cambridge University Press.

Magone, C., M. Neuman \& F. Weissman 2011. Humanitarian negotiations revealed. The MSF experience. London: C. Hirst \& Co Publishers Ltd.

Marriage, Z. 2006. Not Breaking the Rules, not playing the game. International assistance to countries at war. London: Hurst \& Company.

Maskalyk, J. 2009. Six months in Sudan. A young doctor in a war-torn village. Edinburgh: Canongate.

Middleton, N. \& P. O'Keefe 2006. 'Politics, history \& problems of humanitarian assistance in Sudan', Review of African Political Economy 33, 109: 543-559.

Millard Burr, J. \& R. O. Collins 1995. Requiem for the Sudan: War, drought \& disaster relief on the Nile. Boulder: Westview Press.

Pandolfi, M. 2010. 'Humanitarianism and its discontents', in E. Bornstein \& P. Redfield, eds. Forces of compassion. Humanitarianism between ethics and politics. Santa Fe: SAR Press, 227-248.

Pantuliano, S. 2009. International engagement in fragile states: lessons from Southern Sudan. London: ODI.

Pinaud, C. 2014. 'South Sudan: civil war, predation and the making of a military aristocracy', African Affairs 113, 451: 192-211.

Redfield, P. \& E. Bornstein 2011. ‘An introduction to the anthropology of humanitarianism', in E. Bornstein \& P. Redfield, eds. Forces of compassion: humanitarianism between ethics and politics. Santa Fe: SAR Press, 3-30.

Reid-Henry, S. M. 2014. 'Humanitariansim as liberal diagnostic: humanitarian reason and the political rationalities of the liberal will-to-care', Transactions of the Institute of British Geographers 39, 3: 418-431.

Rieff, D. 2011. 'Afterword', in C. Magone \& M. Neuman, eds. Humanitarian negotiations revealed. The MSF Experience. London: C. Hirst \& Co Publishers Ltd, 288-296.

Riehl, V. 2001. 'Who is ruling South Sudan? The role of NGOs in rebuilding socio-political order', Studies on Emergencies and Disaster Relief 9. Uppsala: Nordiska Afrikaistitutet.

Salomons, D. 2015. 'The perils of Dunantism: the need for a rights-based approach to 
humanitarianism', in A. Zwitter, C. K. Lamont, H. J. Heintze \& J. Herman, eds. Humanitarian action. Global, regional and domestic legal responses. Cambridge, Cambridge University Press, 33-53.

Schuller, M. 2012. 'Haiti's bitter harvest. Humanitarian aid in the "Republic of NGOs”, , in A. Donini ed. The golden fleece. Manipulation and independence in humanitarian action. Sterling: Kumarian Press, 171-193.

Smillie, I. 2012. 'The emperor's old clothes. The self-created siege of humanitarian action', in A. Donini , ed. The golden fleece. Manipulation and independence in humanitarian action. Sterling: Kumarian Press, 17-42.

Smirl, L. 2015. Spaces of aid: how cars, compounds and hotels shape humanitarianism. London: Zed Books.

Stern, M. \& Öjendal, J. 2010. 'Mapping the security-development nexus: conflict, complexity, cacaphony, convergence?’', Security Dialogue 41, 5: 5-29.

Stoddard, A., A. Harmer \& M. Hughes 2012. Aid worker security report 2012. Host states and their impact on security for humanitarian operations. London: Humanitarian Outcomes.

Thomas, E. 2015. South Sudan. a slow liberation. London: Zed Books.

Twijnstra, R. 2015. ، "Recycling oil money”: procurement politics and (un)productive entrepreneurship in South Sudan', Journal of Eastern African Studies 9, 4: 685-703.

Veit, A. 2010. Intervention as indirect rule. Civil war and statebuilding in the Democratic Republic of Congo. Frankfurt: Campus Verlag.

\section{NEWSPAPERS}

Sudan Tribune, Paris, 'Cat fight among the South Sudan experts and the failure of peace making', by John Young, 11.6.2015. (http://www.sudantribune.com/spip.php?article55298)

\section{Notes}

\footnotetext{
${ }^{1}$ South Sudan: country of dreams; www.aljazeera.com/programmes/faultlines/2015/04/south-sudan-countrydreams-150414080912909.html

${ }^{2}$ Similar relations emerged over the consolidation of patrimonial rule in pre-war Afghanistan (see Goodhand, 2002).

${ }^{3}$ See the leaked report: http://www.nyamile.com/2015/03/07/draft-report-of-the-au-commission-of-inquiry-onsouth-sudan/. Concerning its withdrawal see: $\underline{\text { http://justiceafrica.org/?p=1800 }}$

${ }^{4}$ What is ‘Saving Lives Together’? http://www.alnap.org/resource/12932

${ }^{5}$ See http://www.sudantribune.com/spip.php?article55710
} 
${ }^{6}$ This was also suggested in African Union draft report that was later withdrawn:

http://www.nyamile.com/2015/03/07/draft-report-of-the-au-commission-of-inquiry-on-south-sudan/ which was discussed and suggested by people during fieldwork there previously.

7 “OCHA white paper” (internal document); and "Humanitarian Access in South Sudan, 2011 in review” (OCHA internal document)

${ }^{8}$ UN OCHA white paper on abuse (unpublished document). 